\title{
Genetic identification of interspecific hybrid of Neotropical catfish species (Pseudoplatystoma corruscans vs. Pseudoplatystoma reticulatum) in rivers of Mato Grosso do Sul State, Brazil
}

\author{
Jussara Oliveira Vaini ${ }^{1}$, Alexéia Barufatti Grisolia ${ }^{2}$, Fernanda Dotti do Prado ${ }^{3}$, \\ and Fábio Porto-Foresti ${ }^{3}$
}

Hybrids of the species Pseudoplatystoma corruscans vs. Pseudoplatystoma reticulatum are extensively traded because they are more docile and precocious compared to their parents. This study aimed to identify the occurrence of hybrid 'Surubim' in rivers of the State of Mato Grosso do Sul, applying molecular techniques. Pseudoplatystoma corruscans, Pseudoplatystoma reticulatum and hybrid 'Surubim' were detected using multiplex PCR and PCR-RFLP in RAG2, GLOBIN, EF1 $\alpha, 18 \mathrm{~S}$ rRNA nuclear genes, and mitochondrial $16 \mathrm{~S}$ rRNA gene. The results revealed the presence of $F_{1}$ hybrids in rivers and the occurrence of genetic introgression, evidenced by the Post- $\mathrm{F}_{1}$ hybrids. Furthermore, discrepancies between the morphological and genetic identification were observed, demonstrating the effectiveness of using different molecular markers for the correct identification of these hybrids. The necessity of implementation of management and conservation projects to maintain the genetic integrity of native species populations threatened by hybridization in the rivers of Mato Grosso do Sul State is evident.

Híbridos envolvendo as espécies Pseudoplatystoma corruscans vs. Pseudoplatystoma reticulatum são amplamente comercializados por apresentarem maior docilidade e precocidade quando comparados aos parentais. Neste trabalho objetivou-se identificar, por meio de técnicas moleculares, a existência de surubins híbridos em rios do estado do Mato Grosso do Sul. Pseudoplatystoma corruscans, Pseudoplatystoma reticulatum e 'Surubim' híbrido foram identificados utilizando as técnicas de PCR multiplex e PCR-RFLP dos genes nucleares RAG2, GLOBINA, EF1 $\alpha, 18 \mathrm{~S}$ rRNA e mitocondrial $16 \mathrm{~S}$ rRNA. Os resultados demonstraram a presença de híbridos $\mathrm{F}_{1}$ em rios e a ocorrência da introgressão genética, evidenciada pelos híbridos Pós- $\mathrm{F}_{1}$. Além disso, foram observadas discrepâncias entre a identificação morfológica e genética, demonstrando a eficácia da utilização de diversos marcadores moleculares para identificação correta destes híbridos. Torna-se evidente a necessidade da implantação de projetos de manejo e conservação, a fim de manter a integridade genética de populações de espécies nativas em rios do estado do Mato Grosso do Sul, que encontram-se ameaçadas pela hibridação.

Key words: Conservation, Fish, Hybridization, Introgression, Molecular markers.

\section{Introduction}

In Brazil, within the species of Pimelodidae most produced by aquaculture are the Pseudoplatystoma corruscans and Pseudoplatystoma reticulatum (Porto-Foresti et al., 2013). Crosses of $P$. corruscans and $P$. reticulatum are being used for the application of hybridization techniques in captivity (Porto-Foresti et al., 2013) and the result from these crosses is either the interspecific hybrid 'Surubim' "Cachapinta" (crossing of the female Pseudoplatystoma reticulatum with the male of Pseudoplatystoma corruscans), or the "Pintachara" (crossing of the female Pseudoplatystoma corruscans with the male of Pseudoplatystoma reticulatum) (Porto-Foresti et al., 2011). The lowest cost in the production, combined with the precocity and docility of hybrids compared to pure breeds stood out among the advantages of interspecific crossing (Carvalho et al., 2008).

Nevertheless, due to the lack of methods for the identification of species and for the supervision and proper management of fish products, hybrids can be confused with their parents and

${ }^{1}$ Faculdade de Ciências Exatas e Tecnologia - Universidade Federal da Grande Dourados (UFGD). Rodovia Dourados - Itahum, Km 12 - Cidade Universitária. CEP: 79.804-970. Dourados, MS, Brazil. jussaravaini@hotmail.com

${ }^{2}$ Faculdade de Ciências Biológicas e Ambientais - Universidade Federal da Grande Dourados (UFGD). Rodovia Dourados - Itahum, Km 12 Cidade Universitária. CEP: 79.804-970. Dourados, MS, Brazil. alexeiagrisolia@ufgd.edu.br

${ }^{3}$ Faculdade de Ciências, Departamento de Ciências Biológicas - Universidade Estadual Paulista “Júlio de Mesquita Filho" (UNESP). Av. Luiz Edmundo Carrijo Coube 14-01, Bairro Vargem Limpa. CEP: 17033-360. Bauru, SP, Brazil. ferprado@ibb.unesp.br, fpforesti@fc.unesp.br 
introduced into natural environments through escapes from fish farm tanks or breeding stations and "pesque-e-pague" sites (Porto-Foresti et al., 2008; Hashimoto et al., 2012a).

The escape of the interspecific hybrid 'Surubim' to the natural environment, along with the lack of mechanisms for its identification, can reduce the genetic integrity of pure parental species, because the hybrid is fertile and can backcross with its pure parentals, causing genetic introgression (Marques, 2002; Porto-Foresti et al., 2008; Hashimoto et al., 2012b).

In Brazil, research has already revealed the occurrence of hybrid 'Surubim' in rivers, which have been used as "pure" breeders in commercial production (Carvalho et al., 2008; Hashimoto et al., 2012b). This fact indicates that precautions must be taken when using these animals, as they can either bring positive results to the Brazilian fish farm, improving its performance, or have a negative impact on natural stocks, reducing biodiversity and leading to the loss of the "pure" native as a genetic resource for the establishment of crossings for production of the interspecific hybrid (Carvalho et al., 2008; Porto-Foresti et al., 2011).

As the unaided visual assessment of the morphological characteristics is not a reliable tool for the identification of hybrids, it is important to use molecular techniques that enable the diagnosis of hybrid fish and the differentiation among the parental species (Toledo-Filho et al., 1994).

Prado et al. (2012a) conducted multiplex PCR and PCR-RFLP analyses of the restriction pattern in nuclear RAG2 (Recombination Activating Gene) and mitochondrial 16SrRNA (Ribosomal RNA) genes in individuals from the natural environment and identified the occurrence of the $\mathrm{F}_{1}$ interspecific hybrid 'Surubim, "Pintachara" and "Cachapinta". According to these authors, this may possibly have occurred due to escapes of hybrids from fish farm tanks or "pesque-epague" establishments of the region, indicating the possibility of contamination of the natural environment with animals from fish farming sites in some regions. The addition of nuclear GLOB ( $\beta$-globin), EF1 $\alpha$ (Elongation factor 1-alpha), and 18SrRNA (Ribosomal RNA) molecular markers enabled the genetic identification of Post-F interspecific hybrid 'Surubim' (Hashimoto et al., 2012b).

Hence, the applicability of these molecular tools for the identification of species that compose the parental lines in natural and farming conditions is clear in regard to monitoring hybrid 'Surubim' in natural and cultured stocks, as well as in
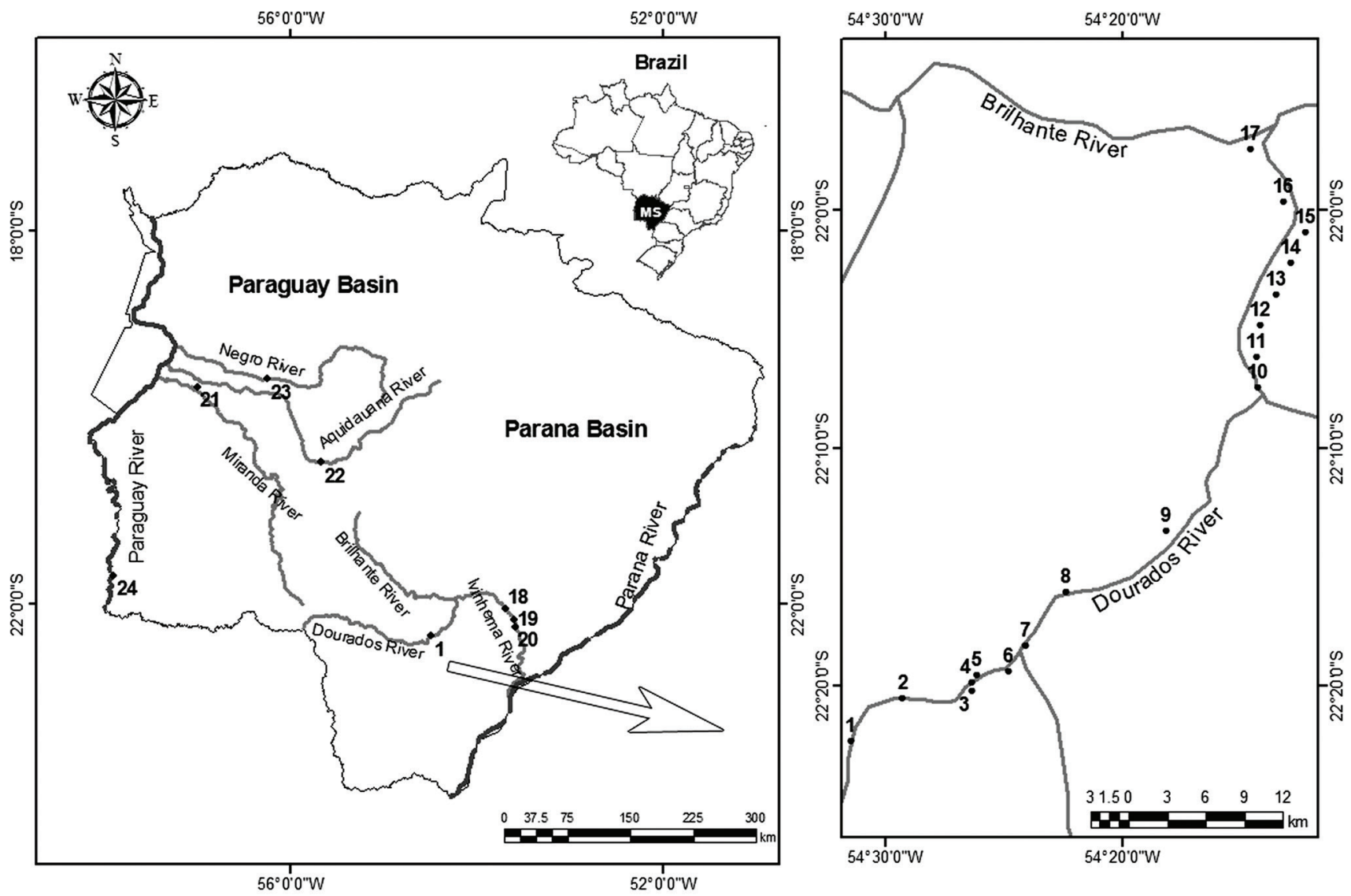

Fig. 1. Map of collection sites of the biological material. Upper Paraná River basin: Dourados River (1 to 16), Brilhante River (17), and Ivinhema River (18 to 20). Paraguay River basin: Miranda River (21), Aquidauana River (22), Negro River (23), and Paraguay River (24). 
Table 1. Description of universal and species-specific primers; Annealing temperature (Ta) in degree Celsius $\left({ }^{\circ} \mathrm{C}\right)$; Size of fragments in base pairs (bp) used in amplification reactions. *Specific for P. corruscans; ** Specific for P. reticulatum.

\begin{tabular}{|c|c|c|c|c|c|}
\hline & Primer & Sequence (5'-3') & Ta $\left({ }^{\circ} \mathrm{C}\right)$ & Size (bp) & Reference \\
\hline \multirow{2}{*}{ Universal } & RAG2 SiluF & CCTGAGTGCTACCTTATTCATGGA & \multirow[t]{2}{*}{$50^{\circ} \mathrm{C}$} & \multirow{2}{*}{550} & \multirow{4}{*}{ (Prado et al. 2011) } \\
\hline & RAG2 SiluR & CTTGGGAGGAAGAGACCATC & & & \\
\hline \multirow{2}{*}{ Species-Specific } & RAG2 PcR* & AACTCCAGGTCAATGAGATAAATG & \multirow{2}{*}{$58^{\circ} \mathrm{C}$} & 330 & \\
\hline & RAG2 PrR** & CAGTTCCAGGTCTCTGTGGTT & & 290 & \\
\hline \multirow{2}{*}{ Universal } & GLOB SiluF & TCAATATGGTTCACTGGACAGA & \multirow{2}{*}{$55^{\circ} \mathrm{C}$} & \multirow{2}{*}{569} & \multirow{4}{*}{$\begin{array}{c}\text { (Hashimoto et al. } \\
\text { 2012b) }\end{array}$} \\
\hline & GLOB SiluR & CCAAGAAGCTGAAAGTAGACAGT & & & \\
\hline \multirow{2}{*}{ Species-Specific } & GLOB PcR* & CAGCCACCTTGGGGTTTCCT & \multirow{2}{*}{$59^{\circ} \mathrm{C}$} & 304 & \\
\hline & GLOB $\operatorname{PrF}^{* *}$ & GGTACGTCTAATCTCAGTAATTGAAA & & 137 & \\
\hline \multirow{2}{*}{ Universal } & $\mathrm{EF} 1 \alpha \mathrm{F}$ & ATTGGAACTGTACCTGTGG & \multirow[t]{2}{*}{$50^{\circ} \mathrm{C}$} & \multirow[t]{2}{*}{800} & \multirow{4}{*}{$\begin{array}{c}\text { (Hashimoto et al. } \\
\text { 2012b) }\end{array}$} \\
\hline & $\mathrm{EF} 1 \alpha \mathrm{R}$ & CAGCCTTCTGTGCAGACTT & & & \\
\hline \multirow{2}{*}{ Species-Specific } & $\mathrm{EF} 1 \alpha \mathrm{PcR}^{*}$ & CAACAATGGCAGCATCTCCT & \multirow[t]{2}{*}{$50^{\circ} \mathrm{C}$} & 520 & \\
\hline & $\mathrm{EF} 1 \alpha \operatorname{PrR} * *$ & ATAAAGGACAAGGACAAGATCG & & 630 & \\
\hline \multirow{2}{*}{ Universal } & $16 \mathrm{SF}$ & ACGCCTGTTTATCAAAAACAT & \multirow[t]{2}{*}{$50^{\circ} \mathrm{C}$} & \multirow{2}{*}{650} & \multirow{4}{*}{ (Prado et al. 2011) } \\
\hline & $16 \mathrm{SR}$ & CGGTCTGAACTCAGATCACGT & & & \\
\hline \multirow{2}{*}{ Species-Specific } & $16 \mathrm{~S} \mathrm{PcF}^{*}$ & TGACCATAAAGATCCGGCTAT & \multirow{2}{*}{$58^{\circ} \mathrm{C}$} & 200 & \\
\hline & $16 \mathrm{~S} \operatorname{PrR} * *$ & TCTTGGTTTTGGGGTTGTTA & & 400 & \\
\hline \multirow{2}{*}{ Universal } & $18 \mathrm{~S}$ NS1F & GTAGTCATATGCTTGTCTC & \multirow[t]{2}{*}{$50^{\circ} \mathrm{C}$} & \multirow{2}{*}{350} & \multirow{2}{*}{$\begin{array}{c}\text { (Hashimoto et al. } \\
\text { 2012b) }\end{array}$} \\
\hline & 18S SiluR & CCATCGAAAAGTTGATAGGG & & & \\
\hline
\end{tabular}

conservation and genetic improvement programs of $P$. corruscans and P. reticulatum (Hashimoto et al., 2012b; Prado et al., 2012a).

The objective of this study was to identify the presence of the interspecific hybrid 'Surubim' resulting from the crossing between Pseudoplatystoma corruscans vs. Pseudoplatystoma reticulatum in rivers of Mato Grosso do Sul State - Brazil, determine the maternal lineage of hybrids ("Cachapinta" or "Pintachara"), verify if the identification based on phenotypic characters corresponds to the molecular-genetic identification, and assess the potential of molecular tools in programs for the conservation and breeding of pure species and also in the betterment of plans for the appropriate management in fish farms and natural environments.

\section{Material and Methods}

\section{Biological material and collection sites}

Fragments of caudal fins of 183 fish (identified as $P$. corruscans, P. reticulatum and interspecific hybrid 'Surubim') were collected from September 2007 to August 2008 and from March 2011 to March 2012 by researchers and fishermen, members of Colônia de Pescadores Artesanais Profissionais "Z-10", município de Fátima do Sul, MS. The fish were collected from the Dourados ( $n=90)$, Ivinhema $(n=49)$ and Brilhante $(\mathrm{n}=11)$ rivers (upper Parana River basin) and from the Negro $(n=17)$, Aquidauana $(n=7)$, Miranda $(n=7)$ and Paraguay $(n=2)$ rivers (Paraguay River basin) (Fig. 1).

\section{Extraction and quantification of DNA}

Total DNA was extracted in the Laboratório de Biotecnologia Aplicada à Produção Animal, of the Faculdade de Ciências Agrárias da Universidade Federal da Grande Dourados (UFGD) - Brazil/MS, following the protocol using 5\% Chelex resin Chelex ${ }^{\circledR} 100$ (Bio-Rad) (Walsh et al., 1991). Approximately 0.1 mg of fin fragment was mixed with $200 \mu \mathrm{L}$ of $5 \%$ Chelex resin and then incubated at $95^{\circ} \mathrm{C}$ for 15 minutes on a thermocycler. After incubation, the sample was centrifuged at $14.000 \mathrm{rpm}$ for $2 \mathrm{~min}$ at $4^{\circ} \mathrm{C}$. The supernatant was transferred to a $1.5 \mathrm{~mL}$ microtube and stored in the freezer $\left(-20^{\circ} \mathrm{C}\right)$ until processing.

The purity $(260 \mathrm{~nm} / 280 \mathrm{~nm})$ and concentration (in $\mathrm{ng} / \mu \mathrm{L}$ ) of the total DNA was determined by optical density measured with a spectrophotometer (NanoPhotometer ${ }^{\mathrm{TM}} \mathrm{P}-300 \mathrm{UV}-\mathrm{Vis}$ of IMPLEN $\left.{ }^{\circledR}\right)$.

\section{Multiplex PCR reactions}

Sequence of universal and species-specific primers utilized, as well as the annealing temperature and size of the generated fragments, are shown in Table 1.

The multiplex PCR reaction techniques used were developed by Prado et al. (2011) for the RAG2 nuclear gene and for the 16S rRNA mitochondrial gene, and those for the nuclear genes GLOB and EF1 $\alpha$, were developed by Hashimoto et al. (2012b). For the 18S rRNA gene, the PCRRFLP was performed (Hashimoto et al., 2012b). 
Table 2. Description of restriction enzymes and size of the fragments in base pairs (bp) generated by restriction enzyme digestion. Pc: Pseudoplatystoma corruscans, Pr: Pseudoplatystoma reticulatum.

\begin{tabular}{llccc}
\hline Gene & $\begin{array}{l}\text { Restriction } \\
\text { enzyme }\end{array}$ & \multicolumn{2}{c}{ Fragment size in bp } & Reference \\
\hline & & Pc & Pr & \\
RAG2 & Sau96I & 300,250 & 550 & Prado et al. 2011 \\
GLOB & HpyAV & 186,381 & 569 & Hashimoto et al. 2012b \\
EF1 $\alpha$ & BpmI & 240,560 & 240,270, & Hashimoto et al. 2012b \\
18S & SmaI & 163,187 & 350 & Hashimoto et al. 2012b \\
$16 \mathrm{~S}$ & SmI & 650 & 330,350 & Prado et al. 2011 \\
\hline
\end{tabular}

The multiplex PCR analysis of nuclear genes (RAG2, GLOB, EF1 $\alpha$ ) and of the 16S rRNA mitochondrial gene was performed in a $25 \mu \mathrm{L}$ final volume and the mixture for amplification of each gene consisted of: $4.9 \mu \mathrm{L}$ of ultrapure water (Fermentas $\mathbb{R}), 0.1 \mu \mathrm{M}$ of each universal and species-specific primer, $12.5 \mu \mathrm{L}$ of PCR Master MIX (50U/ $\mathrm{mL}$ Taq DNA polymerase, $400 \mu \mathrm{M}$ dNTP and $3 \mathrm{mM} \mathrm{MgCl}_{2}$ ) (Fermentas ${ }^{\circledR}$ ) and 10-50ng of total DNA.

The PCR reactions were performed in the thermo cycler model BIORAD MyCyclerTM Thermal Cycler. The protocol used for the multiplex amplification reactions was adapted from Prado et al. (2011) and Hashimoto et al. (2012b) and consisted of the following steps for multiplex PCR of RAG2 and $16 \mathrm{~S}$ genes: one cycle at $95^{\circ} \mathrm{C}$ for $5 \mathrm{~min}$, one cycle at $95^{\circ} \mathrm{C}$ for $30 \mathrm{~s}$, at $58^{\circ} \mathrm{C}$ for $45 \mathrm{~s}$ and at $72^{\circ} \mathrm{C}$ for $20 \mathrm{~s}$, with a total of 30 repeats; and a final cycle at $72{ }^{\circ} \mathrm{C}$ for $5 \mathrm{~min}$. For the multiplex PCR of GLOB and EF1 $\alpha$ genes, only the annealing temperatures varied: $59^{\circ} \mathrm{C}$ and $50^{\circ} \mathrm{C}$ for each gene, respectively. The amplification reactions were visualized on $1.5 \%$ agarose gel stained with ethidium bromide $(10 \mathrm{mg} / \mathrm{mL})$ and visualized by a photo documenter (UVP ${ }^{\circledR}$, PhotoDoc-It 55).

\section{PCR-RFLP Reactions}

The PCR-RFLP was conducted to confirm the results of multiplex PCR. The PCR reaction of each gene was performed with their universal primers (Table 1). The PCR products were digested with restriction enzymes (Table 2) all in a final volume of $8 \mu \mathrm{L}$, with $4 \mu \mathrm{L}$ of the PCR product, $2.7 \mu \mathrm{L}$ of ultrapure water (Fermentas $\left.{ }^{\circledR}\right), 1 \mathrm{X}$ enzyme buffer and $5 \mathrm{U}$ restriction enzyme $(10 \mathrm{U} / \mu \mathrm{L})$. The enzymatic reactions occurred under the optimum temperature of each enzyme for 1 hour according to the instructions of the manufacturer of each enzyme. The digestion reactions were run on $1.5 \%$ agarose gel stained with ethidium bromide $(10 \mathrm{mg} / \mathrm{mL})$ and visualized by a photo documenter $(U V P \circledast$, PhotoDoc-It 55).

\section{Visual and genetic identification}

The FISHER exact test was used to statistically analyze whether visual identification based on morphological characters described by fishermen and/or researchers corresponded to the molecular-genetic identification. The analysis was conducted from a contingency table with significance level $\alpha=5 \%$.

\section{Results}

From the 183 samples analyzed, at first 123 were phenotipically identified by visual inspection as Pseudoplatystoma corruscans, 44 as Pseudoplatystoma reticulatum and 16 as interspecific hybrid 'Surubim'. However, using molecular markers of the RAG2, GLOB, EF1 $\alpha$ and $18 \mathrm{~S}$ rRNA nuclear genes and of the 16S rRNA mitochondrial gene for genetic identification, 76 individuals were classified as $P$. corruscans, 16 as P. reticulatum and 91 as hybrid 'Surubim' ( $68 \mathrm{~F}_{1}$ hybrids and 23 Post- $\mathrm{F}_{1}$ hybrids) (Table 3 ). This means that the visual identification of the animals $(p<0.05)$ did

Table 3. Comparison between the phenotypic and genotypic identification of individuals at each collection site. Genotype in parenthesis, and phenotype outside parenthesis. $\mathrm{N}=$ number of samples; $\mathrm{Pc}=$ Pseudoplatystoma corruscans; $\mathrm{Pr}=$ Pseudoplatystoma reticulatum; $\mathrm{HF}_{1}=\mathrm{F}_{1}$ interspecific hybrid Surubim; Post- $\mathrm{F}_{1}=$ Post- $\mathrm{F}_{1}$ interspecific hybrid Surubim; "Cachapinta"= female of $P$. reticulatum and male of $P$. corruscans; "Pintachara" = female of $P$. corruscans and male of $P$. reticulatum.

\begin{tabular}{|c|c|c|c|c|c|c|c|}
\hline & \multirow{2}{*}{ Coletem Site } & \multicolumn{4}{|c|}{ Phenotype (Genotype) } & \multicolumn{2}{|c|}{$\mathrm{F}_{1}$ hybrids } \\
\hline & & $\mathrm{Pc}$ & $\operatorname{Pr}$ & $\mathrm{H}-\mathrm{F}_{1}$ & Post- $F_{1}$ & Cachapinta & Pintachara \\
\hline \multirow{4}{*}{ Paraguay Basin } & Negro River $(\mathrm{N}=17)$ & $8(2)$ & $9(7)$ & $0(7)$ & $0(1)$ & 0 & 7 \\
\hline & Aquidauana River $(\mathrm{N}=7)$ & $5(2)$ & 2(4) & $0(0)$ & $0(1)$ & 0 & 0 \\
\hline & Miranda River $(\mathrm{N}=7)$ & $6(5)$ & $1(2)$ & $0(0)$ & $0(0)$ & 0 & 0 \\
\hline & Paraguay River $(\mathrm{N}=2)$ & $1(1)$ & $1(1)$ & $0(0)$ & $0(0)$ & 0 & 0 \\
\hline \multirow{3}{*}{ Parana Basin } & Ivinhema River $(\mathrm{N}=49)$ & $27(18)$ & $11(1)$ & $11(22)$ & $0(8)$ & 22 & 0 \\
\hline & Brilhante River $(\mathrm{N}=11)$ & $7(3)$ & $4(0)$ & $0(5)$ & $0(3)$ & 4 & 1 \\
\hline & Dourados River $(\mathrm{N}=90)$ & $69(45)$ & $16(1)$ & $5(34)$ & $0(10)$ & 31 & 3 \\
\hline TOTAL & $\mathrm{N}=183$ & $123(76)$ & $44(16)$ & $16(68)$ & $0(23)$ & 57 & 11 \\
\hline
\end{tabular}


Table 4. Examples of phenotypic and genotypic characterization resulting from the analyses. $\mathrm{Pc}=$ Pseudoplatystoma corruscans; $\mathrm{Pr}=$ Pseudoplatystoma reticulatum.

\begin{tabular}{|c|c|c|c|c|c|c|c|c|c|c|c|}
\hline \multirow{3}{*}{ Phenotype } & \multicolumn{10}{|c|}{ Molecular Markers } & \multirow{3}{*}{ Genotype } \\
\hline & \multicolumn{2}{|c|}{$16 \mathrm{~S}$} & \multicolumn{2}{|c|}{ RAG2 } & \multicolumn{2}{|c|}{ GLOB } & \multicolumn{2}{|c|}{ EF1 } & \multicolumn{2}{|c|}{$18 \mathrm{~S}$} & \\
\hline & $\operatorname{Pr}$ & $\mathrm{Pc}$ & $\operatorname{Pr}$ & $\mathrm{Pc}$ & $\operatorname{Pr}$ & $\mathrm{Pc}$ & $\operatorname{Pr}$ & $\mathrm{Pc}$ & $\operatorname{Pr}$ & $\mathrm{Pc}$ & \\
\hline P.corruscans & & $\mathrm{x}$ & $\mathrm{x}$ & $\mathrm{x}$ & $\mathrm{x}$ & $\mathrm{x}$ & $\mathrm{x}$ & $\mathrm{x}$ & $\mathrm{x}$ & $\mathrm{x}$ & "Pintachara" \\
\hline P.corruscans & $\mathrm{x}$ & & $\mathrm{x}$ & $\mathrm{x}$ & $\mathrm{x}$ & $\mathrm{x}$ & $\mathrm{x}$ & $\mathrm{x}$ & $\mathrm{x}$ & $\mathrm{x}$ & "Cachapinta" \\
\hline P.corruscans & $\mathrm{x}$ & & $\mathrm{x}$ & & $\mathrm{x}$ & & $\mathrm{x}$ & & $\mathrm{x}$ & & P. reticulatum \\
\hline P.corruscans & & $\mathrm{x}$ & & $\mathrm{x}$ & & $\mathrm{x}$ & & $\mathrm{x}$ & & $\mathrm{x}$ & P. corruscans \\
\hline P.reticulatum & & $\mathrm{x}$ & $\mathrm{x}$ & $\mathrm{x}$ & $\mathrm{x}$ & $\mathrm{x}$ & $\mathrm{x}$ & $\mathrm{x}$ & $\mathrm{x}$ & $\mathrm{x}$ & "Pintachara" \\
\hline P.reticulatum & $\mathrm{x}$ & & $\mathrm{x}$ & $\mathrm{x}$ & $\mathrm{x}$ & $\mathrm{x}$ & $\mathrm{x}$ & $\mathrm{x}$ & $\mathrm{x}$ & $\mathrm{x}$ & "Cachapinta" \\
\hline P.reticulatum & $\mathrm{x}$ & & $\mathrm{x}$ & $\mathrm{x}$ & $\mathrm{x}$ & $\mathrm{x}$ & & $\mathrm{x}$ & & $\mathrm{x}$ & Post- $F_{1}$ \\
\hline P.reticulatum & $\mathrm{x}$ & & $\mathrm{x}$ & & $\mathrm{x}$ & & $\mathrm{x}$ & & $\mathrm{x}$ & & P. reticulatum \\
\hline Hybrid & & $\mathrm{x}$ & $\mathrm{x}$ & $\mathrm{x}$ & $\mathrm{x}$ & $\mathrm{x}$ & $\mathrm{x}$ & $\mathrm{x}$ & $\mathrm{x}$ & $\mathrm{x}$ & "Pintachara" \\
\hline Hybrid & $\mathrm{x}$ & & $\mathrm{x}$ & $\mathrm{x}$ & $\mathrm{x}$ & $\mathrm{x}$ & $\mathrm{x}$ & $\mathrm{x}$ & $\mathrm{x}$ & $\mathrm{x}$ & "Cachapinta" \\
\hline Hybrid & & $\mathrm{x}$ & $\mathrm{x}$ & & $\mathrm{x}$ & $\mathrm{x}$ & & $\mathrm{x}$ & $\mathrm{x}$ & & Post- $F_{1}$ \\
\hline Hybrid & $\mathrm{x}$ & & $\mathrm{x}$ & & $\mathrm{x}$ & & $\mathrm{x}$ & & $\mathrm{x}$ & & P. reticulatum \\
\hline
\end{tabular}

not statistically coincide with the genotypic identification. This result shows that the identification based on phenotypic parameters is not an accurate method to characterize animals.

Among the interspecific hybrid 'Surubim' genetically analyzed, the majority was observed in the upper Paraná River basin and identified as "Cachapinta", and in the Paraguay River basin, and identified as "Pintachara" (Table 3).

The individuals were considered "pure" when they presented the $P$. corruscans or the P. reticulatum pattern in the five molecular markers used (RAG2, GLOB, EF1 $\alpha$, $18 \mathrm{~S}$ rRNA, and 16S rRNA); the individuals that exhibited the hybrid pattern in the five markers were identified as " $F_{1}$ hybrid Surubim" ("Pintachara" or "Cachapinta"), and those that presented a different pattern among the markers were identified as "Post-F $F_{1}$ hybrid Surubim" (Table 4).

The methodology used for DNA extraction using 5\% Chelex resin was efficient. This is evidenced by the results obtained from the quantification by spectrophotometry $(260 \mathrm{~nm}$ e $280 \mathrm{~nm})$. The mean concentration of DNA were $225.86 \mathrm{ng} / \mu \mathrm{L}$ and mean ratios 1.77 . Thus, it was possible to extract good quality DNA in a sufficient amount to enable the continuity of the molecular analyses.

\section{Discussion}

Research by Boecklen \& Howard (1997) and Docker et al. (2003) describe the necessity of analyzing at least four nuclear loci to discriminate among pure species, $\mathrm{F}_{1}$ hybrids and backcrossed individuals (Post- $\mathrm{F}_{1}$ ). As $\mathrm{F}_{1}$ hybrids interbreed with other $\mathrm{F}_{1}$ hybrids or backcross with their parents, the subsequent generations (Post- $\mathrm{F}_{1}$ ) will start present genetic similarity with the $\mathrm{F}_{1}$ hybrids or with the wild parents and may well be mistaken even in genotypic analyzes. Therefore, the larger the number of nuclear markers employed, the greater the reliability of the results for the identification of Post- $F_{1}$ hybrids.

In the present study, the use of four nuclear markers (RAG2, GLOB, EF1 $\alpha, 18 \mathrm{~S})$ and one mitochondrial (16S rRNA) marker, enabled the genetic differentiation between P. corruscans, $P$. reticulatum, as well as, the identification of $\mathrm{F}_{1}$ and Post- $\mathrm{F}_{1}$ hybrids, corroborating the results obtained by Hashimoto et al. (2012b).

Prado et al. (2012b), accomplishing cytogenetic analysis, observed that $\mathrm{F}_{1}$ and Post- $\mathrm{F}_{1}$ hybrids between Pseudoplatystoma corruscans vs. Pseudoplatystoma reticulatum from the upper Paraná River basin are fertile, since P. corruscans, P. reticulatum, $\mathrm{F}_{1}$ and Post- $\mathrm{F}_{1}$ Hybrids revealed a cytogenetic pattern with 56 chromosomes uniformly distributed. This homology in the chromosome constitution of the parental species often results in correct pairing and segregation of chromosomes during meiosis, producing viable gametes in interspecific hybrids. This could explain the occurrence of Post- $\mathrm{F}_{1}$ hybrids in the natural environment, as observed in this work.

The greater frequency of "Cachapinta" hybrids in rivers belonging to the upper Paraná River basin may be either due to their escape from fish farm tanks and/or "pesque-e-pague" establishments. The "Cachapinta" is the most traded hybrid by fish farm (Porto-Foresti et al., 2011), because the crosses consisting of females of $P$. reticulatum present a greater reproductive period compared to the females of $P$. corruscans (Campos, 2010). Thus, the majority of fish farms in the State of Mato Grosso do Sul, Brazil are probably using this type of matrix.

The main source of dispersal of cultivated species to the natural environment is the "pesque-e-pague" establishments, because escapes are almost inevitable (Fernandes et al., 2003; Porto-Foresti et al., 2008; Prado et al., 2012a; Hashimoto et al., 2012b). 
The presence of "Pintachara" hybrids in the rivers of the Paraguay basin is presumably explained through the natural hybridization between pure species. According to Genovart (2009) the natural hybridization which albeit rare, can happen.

The examples of hybridization in nature are often attributed to environmental degradation, such as tree felling or any change in the environment, which can lead one species to migrate to another site where it did not previously exist, and there cross naturally with some species phylogenetically close, generating a hybrid that might not exist if man had not degraded the environment (Mallet, 2005; Saura \& Faria, 2011).

Given that the environments under study have been suffering such environmental impacts, it is possible that something similar may have happened to the migratory species of $P$. corruscans and P. reticulatum in the Paraguay River basin. Another important point relates to the possibility that some places (fish farm) present in that basin are performing artificial hybridization with the female of $P$. corruscans.

In the current study, the comparison between visual and genetic identification demonstrated the efficiency of the of molecular marker technology for genetic differentiation between pure species and hybrids, providing basis for the selection of genetically pure crosses in artificial crossing. Furthermore, it enabled the identification of genetic contamination in natural environment, indicating the need for management of escapes of interspecific hybrid 'Surubim' from fish farm, breeding stations and/or "pesque-e-pague" establishments.

Toledo-Filho et al. (1994), Allendorf et al. (2001), Saura \& Faria (2011), Hashimoto et al. (2012b), Pazian et al. (2012), Porto-Foresti et al. (2013) reported the need for the application of molecular techniques combined with visual detection methods to better identify the species and hybrids, since hybrids have morphological characteristics similar to those of their parents, confounding the visual identification. Molecular techniques (multiplex PCR and PCR-RFLP) used in this study and currently employed to identify and differentiate species of fish (Prado et al., 2011; Prado et al., 2012a; Hashimoto et al., 2012b) have been shown to be fast and applicable technologies.

Although hybridization has already been investigated, there are still many controversies on this subject, especially on interspecific hybridization. Questions about the consequences of hybridization between the wild parentals and hybrids; the effects of backcrossing on the natural environment, the role of gene introgression in the evolution of organisms, and to which extent hybridization can determine the extinction of species, are issues still to be studied (Schwenk et al., 2008; Genovart, 2009). Yet, even in the presence of these controversies, there is a clear need for the implementation of monitoring policies and adequate handling of these hybrids in fish farm, in order to maintain the genetic integrity of the species $P$. corruscans and $P$. reticulatum, as has also been corroborated by Porto-
Foresti et al. (2008), Prado et al. (2012b), and Hashimoto et al. (2012a, 2012b).

Thus, prior to performing any study of genetic variability, a previous genetic identification of these individuals is essential so as to distinguish among hybrid and pure bred organisms and not run the risk of utilizing them as pure species.

This research provided a scientific basis for the identification of the interspecific hybrid 'Surubim' situation in the rivers of the State of Mato Grosso do Sul. Furthermore, it also generated data for conducting research on the genetic variability of $P$. corruscans and $P$. reticulatum in the natural environment, management for the selection of pure crosses for conservation and genetic improvement programs of these species, and for the establishment of interspecific crossings in fish farms.

\section{Acknowledgments}

The authors thank Coordenação de Aperfeiçoamento de Pessoal de Nível Superior (CAPES) for its financial support; Universidade Federal da Grande Dourados (UFGD) and Universidade Estadual Paulista "Júlio de Mesquita" (UNESP) - câmpus de Bauru for its logistic support; the fishermen of Colônia de Pescadores Artesanais Profissionais "Z-10" (Fátima do Sul, MS), the Master Vitor Simão Galletti and Dr. Fábio Edir dos Santos Costa for their help with the collection of biological material; the Dr. Joelson Gonçalves Pereira and Chun Pun Hung for their help with the elaboration of the map.

\section{Literature Cited}

Allendorf, F., R. Leary., P. Spruell \& J. Wenburg. 2001. The problems with hybrids: setting conservation guidelines. Trends in Ecology and Evolution, 16: 613-622.

Boecklen, W. J \& D. J. Howard. 1997. Genetic analysis of hybrid zones: numbers of markers and power of resolution. Ecology, 78: 2611-2616.

Campos, J. L. 2010. O cultivo do pintado (Pseudoplatystoma corruscans, Spix; Agassiz, 1829), outras espécies do gênero Pseudoplatystoma e seus híbridos. Pp. 335-361. In: Baldisserotto, B. \& L. C. Gomes (Eds.). Espécies nativas para a piscicultura no Brasil. Santa Maria, Universidade Federal de Santa Maria.

Carvalho, D. C., A. Seerig., D. C. Melo., A. B. Sousa., D. Pimenta \& D. A. A. Oliveira. 2008. Identificação molecular de peixes: o caso do Surubim (Pseudoplatystoma spp.). Revista Brasileira de Reprodução Animal, 32: 215-219.

Docker, M. F., A. Dale \& D. D. Heath. 2003. Erosion of interspecific reproductive barriers resulting from hatchery supplementation of rainbow trout sympatric with cutthroat trout. Molecular Ecology, 12: 3515-3521.

Fernandes, R., L. C. Gomes \& A. A. Agostinho. 2003. Pesquepague: negócio ou fonte de dispersão de espécies exóticas? Acta Scientiarum: Biological Sciences, 25: 115-120.

Genovart, M. 2009. Natural hybridization and conservation. Biodiversity and Conservation, 18: 1435-1439.

Hashimoto, D. T., J. A. Senhorini, F. Foresti \& F. Porto-Foresti. 2012a. Interspecific fish hybrids in Brazil: management of genetic 
resources for sustainable use. Reviews in Aquaculture, 4: 108-118.

Hashimoto, D. T., F. D. Prado., J. A. Senhorini, F. Foresti \& F. PortoForesti. 2012b. Detection of post-F fish hybrids in broodstock using molecular markers: approaches for genetic management in aquaculture. Aquaculture Research, 1-9.

Mallet, J. 2005. Hybridization as an invasion of the genome. Trends in Ecology and Evolution, 20: 229-237.

Marques, D. K. S. 2002. Aplicação da biologia molecular em programas de conservação de recursos pesqueiros. Embrapa Pantanal, Corumbá.

Pazian, M. F., L. H. G. Pereira, C. K. Shimabukuru-Dias, C. Oliveira \& F. Foresti. 2012. Cytogenetic and molecular markers reveal the complexity of the genus Piabina Reinhardt, 1867 (Characiformes: Characidae). Neotropical Ichthyology, 10: 329-340.

Porto-Foresti, F., D. T. Hashimoto, A. L. Alves, R. B. C. Almeida, J. A. Senhorini, J. Bortolozzi \& F. Foresti. 2008. Cytogenetic markers as diagnoses in the identification of the hybrid between Piauçu (Leporinus macrocephalus) and Piapara (Leporinus elongatus). Genetics and Molecular Biology, 31: 195-202.

Porto-Foresti, F., D. T. Hashimoto, F. D. Prado, J. A. Senhorini \& F. Foresti. 2011. A hibridação interespecífica em peixes. Panorama da Aquicultura, 21: 28-33.

Porto-Foresti, F., D. T. Hashimoto, F. D. Prado, J. A. Senhorini \& F. Foresti. 2013. Genetic markers for the identification of hybrids among catfish species of the family Pimelodidae. Journal of Applied Ichthyology, 29: 643-647.

Prado, F. D., D. T. Hashimoto, F. F. Mendonça, J. A. Senhorini, F. Foresti \& F. Porto-Foresti. 2011. Molecular identification of hybrids between Neotropical catfish species Pseudoplatystoma corruscans and Pseudoplatystoma reticulatum. Aquaculture Research, 42: 1890-1894.
Prado, F. D., D. T. Hashimoto, F. F. Mendonça, J. A. Senhorini, F. Foresti \& F. Porto-Foresti. 2012a. Detection of hybrids and genetic introgression in wild stocks of two catfish species (Siluriformes: Pimelodidae): The impact of hatcheries in Brazil. Fisheries Research, 125-126: 300-305.

Prado, F. D., T. L. Nunes, J. A. Senhorini, J. Bortolozzi, F. Foresti \& F. Porto-Foresti. 2012b. Cytogenetic characterization of $F_{1}$, $\mathrm{F}_{2}$ and backcross hybrids of the Neotropical catfish species Pseudoplatystoma corruscans and Pseudoplatystoma reticulatum (Pimelodidae, Siluriformes). Genetics and Molecular Biology, 35: 57-64.

Saura, M \& R. Faria. 2011. Genetic tools for restoration of fish populations. Journal of Applied Ichthyology, 27: 5-15.

Schwenk, K., N. Brede \& B. Streit. 2008. Introduction. Extent, processes and evolutionary impact of interspecific hybridization in animals. Philosophical Transactions of the Royal Society Biological Sciences, 363: 2805-2811.

Toledo-Filho, S. A., L. F. Almeida-Toledo, F. Foresti, G. Bernardinho \& D. Calcagnotto. 1994. Monitoramento e conservação genética em projeto de hibridação entre pacu e tambaqui. Universidade de São Paulo, São Paulo.

Walsh, P. S., D. A. Metzger \& R. Higuchi. 1991. Chelex-100 as a medium for simple extraction of DNA for PCR-based typing from forensic material. Biotechniques, 10: 506-513.

Submitted October 4, 2013

Accepted February 6, 2014 by Alexandre Hilsdorf

Published September 30, 2014 